\title{
MICROFLORA ASSOCIATED WITH PROCESSING AND STORAGE OF THE WHITE CATFISH (CHRYSICHTHYS NIGRODIGITATUS)
}

\author{
NWACHUKWU, V. N*1 AND MADUBUKO C. U*2 \\ Department Of Fisheries Technology Federal Polytechnic Nekede Owerri, Imo State.
}

Copyright 2010, Fisheries Society of Nigeria.

This paper was prepared for presentation at the $25^{\text {th }}$ Annual International Conference and Exhibition in Administrative Staff College of Nigeria (ASCON), Topo-Badagry, Lagos, Nigeria, $25^{\text {th }}-29^{\text {th }}$ October, 2010.

This paper was selected for presentation by an FISON Program Committee following review of information contained in an abstract submitted by the author(s). Contents of the paper, as presented, have not been reviewed by the Fisheries Society of Nigeria and are subject to correction by the author(s). The material, as presented, does not necessarily reflect any position of the Fisheries Society of Nigeria, its officers, or members. Papers presented at Fisheries Society of Nigeria, its officers, or members. Papers presented at the Fisheries Socition the Fisheries Society of Nigeria. Electronic reproduction, distribution, or storage of any part of this paper for commercial purposes without the writen consent of the Fisheries Society of Nigena is prohibited. Permission to reproduce in print is restricted to an abstract of not more than 300 words; illustrations may not be copied. The abstract must contain conspicuous acknowledgement of where and by whom the paper was presented. Write Librarian, Fisheries Society of Nigeria (FISON), P. O. Box 2607 Apapa, Lagos.

\section{ABSTRACT}

Quality deterioration (microbial load) of smoked white catfish (chrysichthys nigrodigitatus) from Ekeonunwa market Imo state Nigeria, was studied for six weeks. The experimental fish was divided into two batches. One batch of 18 fishes with average weight of $700 \mathrm{~g}$ was resmoked weekly at $75^{\circ} \mathrm{C}$. the second batch of 18 fishes weighing an average of $750 \mathrm{~g}$ was left unresmoked. Weekly samples of both unresmoked and resmoked fish were taken from different regions (body flanks, gill and gut) and analyzed in the laboratory. Total plate counts (TPC) for the bacterial organisms in both resmoked and unresmoked samples (Table III) ranging between $1.56 \times 10^{5}$ and TNTC ( too numereous to count) exceeded the range of specified microbiological limits recommended for fish and fishery products by ICMSF (1986). Pathogenic organisms isolated included Escherichia coli, Staphylococcus aureus, Lysteria monocytogenes, Bacillus cereus, Aspergillus flavus, Penicillium varrucossum, Yeast and Mucor. Both unresmoked and resmoked fish specimens were contaminated with these spoilage microbes, but the microbial load of the resmoked samples were less than those of the unresmoked samples. Resmoking beneficially reduces microbial load of stored fish, increases the shelf/storage life, but can not totally eliminate pathogens. The presence of pathogens raises a public health concern.

\section{INTRODUCTION}

Fishes are a very perishable commodity and its spoilage is as a result of both enzymatic and bacterial breakdown of the flesh, especially in the tropics where temperatures are high. There is therefore need to preserve fish in someway after capture to prevent loss due to spoilage and to provide an excellent "just caught flavor". Technically, smoking is the process through which volatiles from thermal combustion of wood penetrate meat and fish flesh (Simko, 1991). The quality of smoked product depends on the quality of the fish at the time of smoking, the nature of wood and the type of smoking procedure employed Doe et al, (1998).Delay of microbial spoilage of fish may be achieved by introduction of different additives such as sodium lactate to inhibit Listeria monocytogenes and Clostridium botulinium and it's toxin production; sodium chloride inhibiting the growth of L.monocytogenes and prevent the germination of C.botilinium endospore; Ascorbic acid utilized to prevent mold growth in smoked fish during storage; and Rosemary extract with ascorbic acid inhibits oxidative deterioration (USDA, 1999) (Doe et al, 1998).The objective of the study is: 1 .To determine the microbial load of unresmoked and resmoked white catfish stored at room temperature. 2. To determine physical quality changes of unresmoked and resmoked white catfish stored at room temperature. 3. To determine a non toxic protocol of 
managing and increasing the storage life of smoked catfish.

\section{MATERIALS AND METHODS}

This study was carried out with samples obtained from dried fish sellers at Ekeonunwa market, Owerri, Imo state of Nigeria.

\section{SAMPLE COLLECTION AND METHODS}

Freshly smoked white catfish was bought and divided into two parts tagged, unresmoked and resmoked samples (which was resmoked once every week in a hot air oven). Samples from the body, gill and gut were reduced to fine particles and diluted with $10 \mathrm{ml}$ of distilled water, giving a final concentration of $1 \mathrm{~g} / 10 \mathrm{ml}$. $1 \mathrm{ml}$ was added to $9 \mathrm{ml}$ of distilled water in a sterile test tube to provide $10^{-1}$ dilution and $10^{-4}$ subsequently (Adegoke and Skura1994). Total bacterial counts were determined by inoculating $0.1 \mathrm{ml}$ of the dilution $10^{-3}$ onto Nutrient agar, Maconkey agar and Blood agar by streak method and incubated at $37^{\mathrm{OC}}$ for 24 hours while fungal counts were on sabouraud and Dextrose agar incubated at room temperature $\left(25-26^{\mathrm{OC}}\right)$ for $2-4$ days. All innoculation were done in triplicate.

\section{Identification Of Isolates}

Bacterial isolates were identified using colonial morphology, pigmentation, cell shape and gram staining reaction and biochemical test as described by Singleton (1999), Isu and Onyeagba (1998) and CruickShank et al (1982)

\section{Gram Staining}

The method described by Monica Cheesbrough, (2004) was adopted to classify the organisms as gram negative or gram positive bacteria.

\section{Biochemical Teste For The Bacterial Isolates}

Several tests were carried out to identify the bacterial isolates

\section{Catalase Test}

The organism releases the enzyme catalase which catalyzes the release of oxygen from hydrogen peroxide $2 \mathrm{H}_{2} \mathrm{O} 2 \rightarrow 2 \mathrm{H}_{2 \mathrm{O}}+$ $\mathrm{O}_{2}$.

\section{Coagulase Test}

This identifies staphylococcus aureus which produces the enzyme coagulese.

\section{Indole Test}

This identifies organisms that produce indole from utilizing amino acid from tryptophan e.g. strains of E.coli, P.rettger, P.vulgans and Providencia species.

\section{Oxidase Test}

This test was used to detect the presence of cytochrome oxide in micro organism differentiating pseudomonas and other gram negative rod like Neisseri, Vibrio, Brucclla and pasteurella species.

\section{Citrate Utilization Test}

Enterobacteria is identified by this test which is based on the ability of the organism to use citrate as its only source of carbon.

\section{Motility Test}

This was carried out in semi-solid agar medium and growth from the line of inoculation was recorded as evidence of motility.

\section{Spore Stain}

These were identified by examination under oil immersion objective of stained heat fixed slides.

\section{Identification Of Fungal Isolates}

This was carried out according to Cheesborough (2004). Identification was based on colonial morphology, macroscopic and microscopical examination of the fungal growth on sabouraud dextrose agar. The keys include - growth rates, general topography, surface texture pigmentation and pigmentation of the reverse side of the plates.

\section{RESULTS}

Results of the bacterial and fungal isolates present in the unresmoked and resmoked catfish Chrysichthys nigrodigitatus are represented below. 
TABLE I: Total viable count of bacterial isolates from unresmoked and resmoked catfish on MAC, NA and blood agar.

\begin{tabular}{|c|c|c|c|c|c|c|c|c|}
\hline Parts of fish & Treatment & $\begin{array}{l}\text { No of } \\
\text { bac. } \\
\text { Isolates }\end{array}$ & $\begin{array}{l}\text { Week } \\
\text { I }\end{array}$ & $\begin{array}{l}\text { Week } \\
\text { II }\end{array}$ & $\begin{array}{l}\text { Week } \\
\text { III }\end{array}$ & $\begin{array}{l}\text { Week } \\
\text { IV }\end{array}$ & $\begin{array}{l}\text { Week } \\
\text { V }\end{array}$ & $\begin{array}{l}\text { Week } \\
\text { VI }\end{array}$ \\
\hline \multirow[t]{2}{*}{ BODY(FLANKS) } & UNRESMOKED & 6 & 8 & 73 & TNTC & TNTC & TNTC & TNTC \\
\hline & RESMOKED & 7 & 8 & 15 & 80 & 185 & 245 & 250 \\
\hline \multirow[t]{2}{*}{ GUT } & UNRESMOKED & 6 & 15 & 105 & TNTC & TNTC & TNTC & TNTC \\
\hline & RESMOKED & 7 & 12 & 20 & 110 & 260 & 290 & 320 \\
\hline \multirow[t]{2}{*}{ GILL } & UNRESMOKED & 6 & 12 & 95 & TNTC & TNTC & TNTC & TNTC \\
\hline & RESMOKED & 7 & 10 & 17 & 90 & 210 & 270 & 300 \\
\hline
\end{tabular}

TABLE II: Total viable count of fungal isolates from smoked and resmoked catfish on SDA and Lactophenol mount.

\begin{tabular}{|c|c|c|c|c|c|c|c|c|}
\hline Parts of fish & Treatment & $\begin{array}{l}\text { No of } \\
\text { bac. } \\
\text { Isolates }\end{array}$ & Week I & $\begin{array}{l}\text { Week } \\
\text { II }\end{array}$ & $\begin{array}{l}\text { Week } \\
\text { III }\end{array}$ & $\begin{array}{l}\text { Week } \\
\text { IV }\end{array}$ & $\begin{array}{l}\text { Week } \\
\text { V }\end{array}$ & $\begin{array}{l}\text { Week } \\
\text { VI }\end{array}$ \\
\hline \multirow{2}{*}{ BODY(FLANKS) } & UNRESMOKED & 5 & 6 & 65 & 255 & TNTC & TNTC & TNTC \\
\hline & RESMOKED & 5 & 7 & 60 & 135 & TNTC & 320 & 410 \\
\hline \multirow[t]{2}{*}{ GUT } & UNRESMOKED & 5 & 5 & 65 & 250 & TNTC & TNTC & TNTC \\
\hline & RESMOKED & 5 & 6 & 55 & 100 & TNTC & 280 & 345 \\
\hline \multirow[t]{2}{*}{ GILL } & UNRESMOKED & 5 & 6 & 75 & 255 & TNTC & TNTC & TNTC \\
\hline & RESMOKED & 5 & 7 & 60 & 135 & TNTC & 230 & 375 \\
\hline
\end{tabular}

TABLE III: Mean total viable count of both bacterial and fungal isolates from unresmoked and resmoked catfish

\begin{tabular}{|c|c|c|c|c|c|c|c|}
\hline $\begin{array}{l}\text { Microorganisms } \\
\text { Isolated }\end{array}$ & Treatment & $\begin{array}{l}\text { Week } \\
\text { Cfu/g }\end{array}$ & $\begin{array}{l}\text { Week II } \\
\mathrm{Cfu} / \mathrm{g}\end{array}$ & $\begin{array}{l}\text { Week III } \\
\text { Cfu/g }\end{array}$ & $\begin{array}{l}\text { Week IV } \\
\text { Cfu/g }\end{array}$ & $\begin{array}{l}\text { Week V } \\
\text { Cfu/g }\end{array}$ & $\begin{array}{l}\text { Week VI } \\
\text { Cfu/g }\end{array}$ \\
\hline \multirow[t]{2}{*}{ BACTERIAL } & UNRESMOKED & $\begin{array}{l}11.6 \\
1.16 \times 10^{5}\end{array}$ & $\begin{array}{l}91 \\
9.1 \times 10^{5}\end{array}$ & TNTC & TNTC & TNTC & TNTC \\
\hline & RESMOKED & $\begin{array}{l}10 \\
1.0 \times 10^{5}\end{array}$ & $\begin{array}{l}17.3 \\
1.73 \times 10^{5}\end{array}$ & $\begin{array}{l}93.3 \\
9.33 \times 10^{5}\end{array}$ & $\begin{array}{l}216.6 \\
2.166 \times 10^{6}\end{array}$ & $\begin{array}{l}268.3 \\
2.683 \times 10^{6}\end{array}$ & $\begin{array}{l}290 \\
2.90 \times 10^{6}\end{array}$ \\
\hline \multirow[t]{2}{*}{ FUNGAL } & UNRESMOKED & $\begin{array}{l}15.6 \\
1.56 \times 10^{5}\end{array}$ & $\begin{array}{l}68.3 \\
6.83 \times 10^{5}\end{array}$ & $\begin{array}{l}253.3 \\
2.533 \times 10^{6}\end{array}$ & TNTC & TNTC & TNTC \\
\hline & RESMOKED & $\begin{array}{l}6.6 \\
.66 \times 10^{4}\end{array}$ & $\begin{array}{l}58.3 \\
5.83 \times 10^{5}\end{array}$ & $\begin{array}{l}123.3 \\
1.23 \times 10^{6}\end{array}$ & TNTC & $\begin{array}{l}276.6 \\
2.766 \times 10^{6}\end{array}$ & $\begin{array}{l}376.6 \\
3.76 \times 10^{6}\end{array}$ \\
\hline
\end{tabular}




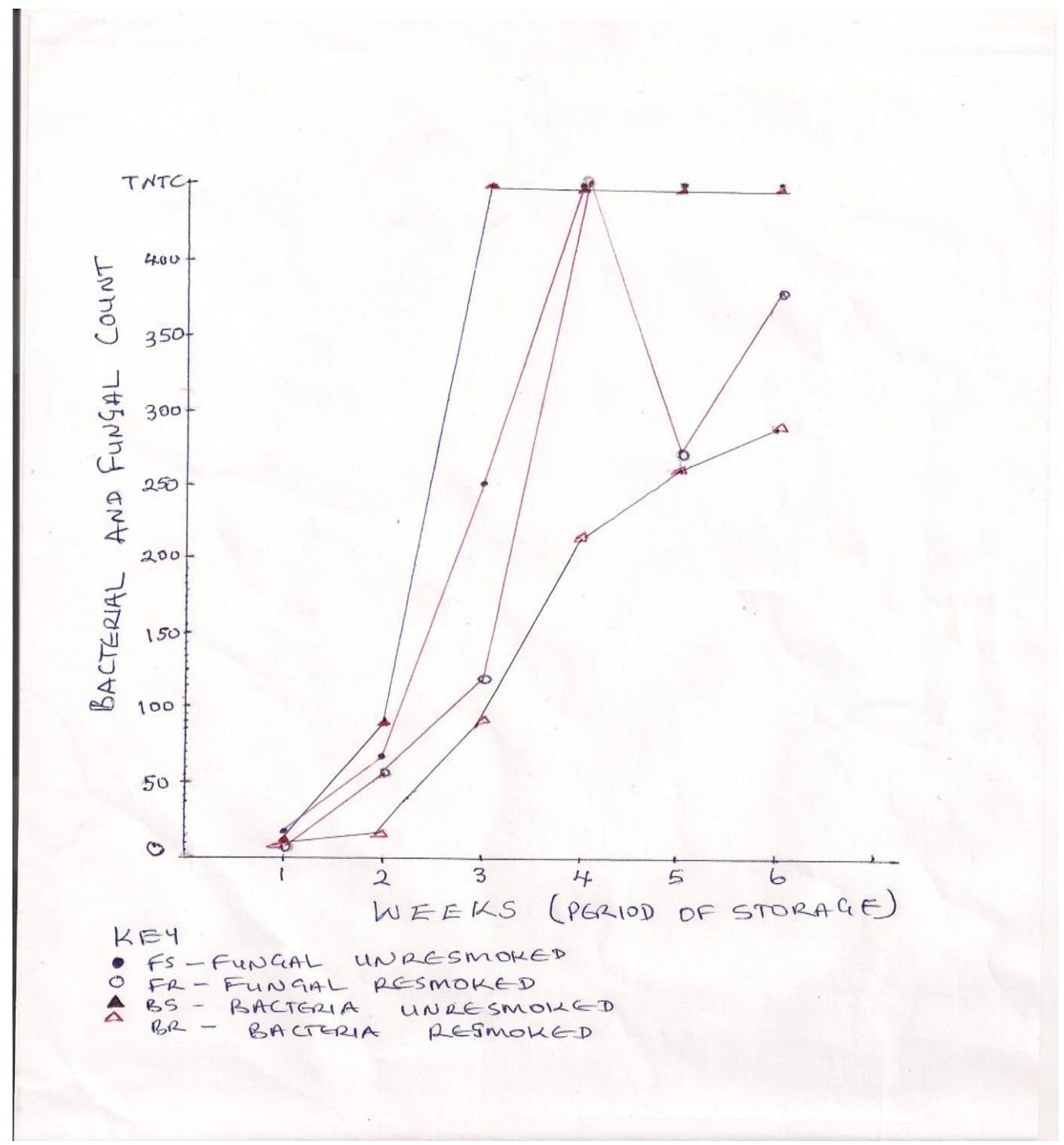

Figure I : micro flora (bacterial and fungal) counts from smoked and resmoked white catfish chryschthys nigrodigitatus

\section{DISCUSSION}

The result of the study revealed that all is not well with the quality of smoked dry white catfish ( $C$. nigrodigitatus) sold in Nigerian markets. The isolation of pathogenic and spoilage organisms such as E.coli, Staphylococcus aureus, Listeria monocytogenes, Aspergillus flavus etc raises public health concerns about safety in consuming smoked fish products from our markets and cause a high rate of spoilage leading to shorter shelf/storage life of the product (Ramos, 1999). Tainting of fish with these organisms is attributed mainly to poor handling by processors and traders who expose smoked fish to unsanitary conditions (FDA, 2001). Total plate counts (TPC) for the bacterial organisms in both resmoked and unresmoked samples (Table III) ranging between $1.56 \times 10^{5}$ and TNTC (too numereous to count) exceeded the range of specified microbiological limits recommended for fish and fishery products by ICMSF (1986). The ICMSF protocol recommends a maximum bacterial count of $5 \times 10^{5}$ for good quality product and a maximum count of $10^{7}$ for marginally acceptable quality products. The good effects of resmoking on the shelf life of the smoked fish by inhibiting growth of spoilage organisms was demonstrated. (Table I and figure I). Table I revealed that bacterial growth in all the resmoked 
regions of the fish never attained the TNTC level, unlike growth in the unresmoked corresponding samples which all reached the TNTC growth ceiling. This shows that resmoking inhibited bacterial growth more than fungal growth (Tables I and II). Some of the diseases caused by these microbes are listeriosis manifesting as meningitis, abortion and pre-natal septicemia affecting mostly immunocompromised individuals, pregnant women and infants E.coli causes life threatning epidemic gastroenteritis in humans e.g travellers diarrhea (ETEC) also called "Delhi belly". Baccillus cereus produces toxins that cause a disease that is more an intoxication than a food borne infection. Also S.aureus is known to cause enterotoxigenicity due to the production of enterotoxin and also known to cause staphylococcus food poisoning which is a major type of food intoxication (Abalaka and Elegbade 1981).

\section{CONCLUSION}

It was noted that stored smoked dried C.nigrodigitatus sold in Ekeonunwa market, Owerri Imo state, was contaminated with pathogenic and spoilage organisms even when resmoked. This finding has both storage and public health implications. It is noted that fish processor and vendors should improve handling hygiene and consumers should also cook smoked fish properly to minimise early spoilage and possible health harzards.

\section{REFERENCES}

Adegoke, G.O and Skura, B.J. (1994) Nutritional profile and antimicrobial spectrum of the species Aframinim danileli $\mathrm{K}$. Shum, plant food for human nutrition US, 1750182.
Cheesbrough, M. (2002) Biochemical tests to identify bacteria. In: District laboratory practice in tropical countries, Cambrigde Low - price edition pp 63-70.

Cruick Shank, R.J.P, Dugid, B.P, Mrimion J.M and Swan, H. (1982). The practice of medical and microbiology $13^{\text {th }}$ edition: Churchill living stone, Edinburgh. Pp 56-58.

Doe, P.E. (1998). Fish drying and smoking production and quality. Technomic publishing co, Inc. Lancaster, Pennsylvania.

ICMSF (International commission on microbiological specification for foods) (1986). Micro organisms in foods 2. Sampling for microbiological analysis. Principles and specification, $2^{\text {nd }}$ ed. Oxford; Blackwell science.

Isu, N.R. and Onyeagba, R.A (1998). Basic practical in microbiology. $1^{\text {st }}$ edition Fasmen communication, Okigwe, Nigeria. Pp 54-68.

Ramos, M.R. (1999) Reduction of endogenous bacteria associated with catfish (Ictalurus punctatus) fillets using the Grovac process. A dissertation Louisiana state UniversityBaton Rouge.

Simko, P. (1991) changes of Bemo (a) Pyrene content in smoked fish during storage. Food chem. 40:293-300

Singleton, P. (1999). Bacteria in Biotechnology and medical $4^{\text {th }} \mathrm{Ed}$., John Wilson and sons limited. New york.Pp 347, 349 and 375.

United states department of agriculture, National Agriculture statiatics service (1999). Catfish production December 1999. Washington DC. 